\title{
The roles of Polycomb group proteins in hematopoietic stem cells and hematological malignancies
}

\author{
Emi Takamatsu-Ichihara ${ }^{1} \cdot$ Issay Kitabayashi $^{1}$
}

Received: 15 March 2016 / Revised: 7 April 2016 / Accepted: 7 April 2016 / Published online: 16 April 2016

(C) The Japanese Society of Hematology 2016

\begin{abstract}
Polycomb group (PcG) proteins are epigenetic regulatory factors that maintain the repression of target gene expression through histone modification. PcG proteins control the repression of genes that regulate differentiation and the cell cycle in the maintenance of hematopoietic stem cells (HSC). Moreover, abnormalities in expression level and mutations in $\mathrm{PcG}$ genes have been reported in various types of cancer, including hematological malignancies. In this review, we present an overview of the roles of $\mathrm{PcG}$ proteins in HSC and various types of hematological malignancies.
\end{abstract}

Keywords Polycomb group proteins $\cdot$ Stem cells · Leukemia $\cdot$ Transcription repression

\section{Introduction}

The expression of genes is regulated by epigenetic systems not associated with changes in the DNA base sequence, including DNA methylation, histone modification, chromatin remodeling factors, and non-coding RNA [1]. As the gene expression patterns regulated through these epigenetic modifications are faithfully reproduced across cell division, epigenetic modifications play a crucial role in biological phenomena such as development, differentiation, and senescence. Moreover, abnormalities in epigenetic modifications such as DNA methylation and histone modification

Issay Kitabayashi

ikitabay@ncc.go.jp

1 Division of Hematological Malignancy, National Cancer Center Research Institute, 5-1-1 Tsukiji, Chuo-ku, Tokyo 104-0045, Japan have been observed in various types of cancer, which indicates that the breakdown of epigenetic regulatory mechanisms is a strong contributor to carcinogenesis [2].

Polycomb group (PcG) proteins are epigenetic regulatory factors that adjust gene expression levels through histone modification. These proteins form the Polycomb complexes PRC1 and PRC2 in the nucleus and maintain repression of target gene expression [3]. PcG protein-controlled repression of genes that regulate differentiation and the cell cycle has been shown to be important in the maintenance of embryonic stem cells (ES cells) and somatic stem cells such as hematopoietic stem cells (HSC) [4, 5]. Additionally, abnormalities in PcG proteins such as high expression and mutations have been observed in various types of cancer including hematopoietic cancer, which suggests that they may be involved in carcinogenesis. This paper, which focuses on HSC and hematological malignancies, will provide an overview of the roles of $\mathrm{PcG}$ proteins with reference to the latest findings and an introduction to therapeutic drugs that target $\mathrm{PcG}$ proteins.

\section{Polycomb group genes}

PcG genes were first identified as genes regulating the expression of homeotic genes that determine the longitudinal axis of the body and segmentation in Drosophila [6]. Drosophila is known to have at least 18 different PcG genes, and multiple homologs for each gene have been identified in mammals. PcG proteins encoded by PcG genes form massive Polycomb repressive complexes (PRCs) in the nucleus. PRCs can be broadly classified according to their biological characteristics as one of two types, PRC1 or PRC2. PRC2 is formed of proteins such as SUZ12, EED, and EZH1/2. EZH1/2 functions as a histone methyltransferase and 


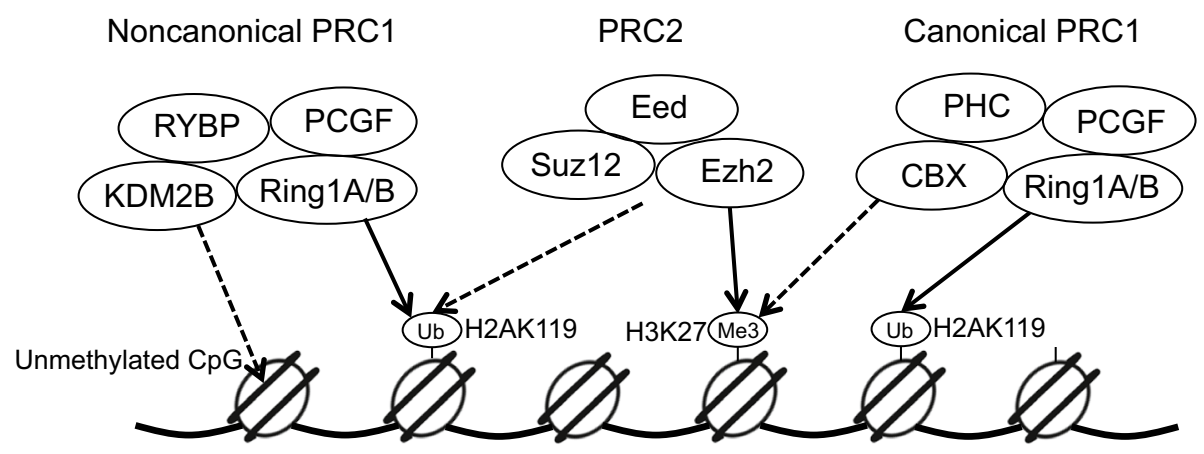

Fig. 1 Model of epigenetic regulation by PRC1 and PRC2. Canonical PRC1 is recruited to target sites through recognition of H3K27me3 by CBX. Noncanonical PRC1 is recruited to unmethylated $\mathrm{CpG}$ islands by KDM2B and ubiquitinates H2AK119 indepen-

trimethylates histone $\mathrm{H} 3$ lysine 27 (H3K27me3) [7, 8]. EED and SUZ12 are necessary factors for recruitment of PRC2 to nucleosomes and histone methyltransferase activity $[9,10]$. $\mathrm{H} 3 \mathrm{~K} 27 \mathrm{me} 3$ formed by PRC2 is a repressive histone modification that induces gene silencing, and PRC1 is recruited to nucleosomes upon recognition of this histone mark. PRC1 is formed of four main constituent factors: Ring1A/B, PCGF, $\mathrm{CBX}$, and PHC. Ring1A/B has ubiquitin ligase activity and ubiquitinates histone $\mathrm{H} 2 \mathrm{~A}$ at lysine 119 [11]. CBX is a chromodomain protein that contributes to recognition of $\mathrm{H} 3 \mathrm{~K} 27 \mathrm{me} 3$ and recruitment of PRC1 to nucleosomes [12]. PCGF (MEL18, BMI1) is a cofactor of Ring1A/B that increases the ubiquitin ligase activity of Ring $1 \mathrm{~A} / \mathrm{B}$ [13]. The ubiquitinated H2AK119 formed by PRC1 plays a central role in repressing the transcription of Polycomb target genes and has been shown to repress transcription by RNA polymerase II [14]. Moreover, PRC1 can condense chromatin and is believed to function as another mechanism of repressing transcription [15]. Many recent studies have shown that constituent factors of PRC1 and their patterns of combination are diverse and there are even differences in function $[16,17]$. Noncanonical PRC1 proteins that do not include CBX but include RYBP or KDM2B are recruited to target sites independently of PRC2 and ubiquitinate H2AK119 [18]. A new model in which ubiquitination of H2AK119 by these noncanonical PRC1 proteins recruits PRC2 to target sites and induces H3K27me3 has also been proposed [19, 20] (Fig. 1).

It appears that there may be several mechanisms by which PcG proteins approach chromatin target sites. Several Polycomb response elements (PREs) that are recognized by PcG proteins have been discovered in Drosophila. PREs have also been found in mice [21], but have only been mentioned in a few studies. One study in mice involving analysis using ES cells showed that PRC1 and PRC2 accumulate in domains with a high density of unmethylated dently of PRC2. PRC1-dependent H2AK119ub1 leads to recruitment of PRC2 and trimethyla1on of H3K27. Solid arrows represent histone modification by PRCs, whereas dashed arrows represent recruitment of PRCs

CpG motifs [22]. Actually, whereas canonical PRC1 proteins recognize $\mathrm{H} 3 \mathrm{~K} 27 \mathrm{me} 3$ through $\mathrm{CBX}$, noncanonical PRC1 proteins recognize unmethylated $\mathrm{CpG}$ islands through their KDM2B subunit and ubiquitinate H2AK119 [19]. Results of recent studies also indicate that transcription factors including Gatal [23], Hic1 [24], Rest [25], and the Runx1/CBF $\beta$ complex [26] recruit Polycomb complexes to specific target genes. Binding to the non-coding RNAs Xist, HOTAIR, and ANRIL is another recognized mechanism of Polycomb recruitment [27].

\section{The role of Polycomb group proteins in hematopoietic stem cells}

Stem cells are cells that serve as the root of all tissue-forming cell populations because they can self-renew and are pluripotent, meaning that they can differentiate into cells with multiple different functions. Polycomb complexes contribute to the maintenance of stem cells such as ES cells and HSCs by repressing gene expression through histone modification [4, 5]. ES cells have bivalent domains in which repressive histone modification by PRC1/2 and activating histone modification by trithorax-group (TrxG) complexes overlap at the same promoter site of the target gene [22]. These bivalent domains regulate the differentiation of stem cells by controlling the on/off switches for genes regulating differentiation and genes related to the cell cycle. It has also been found that tissue stem cells share bivalent domains and HSCs have them as a system for regulating differentiation [28].

\section{PRC1 members in hematopoietic stem cells}

Analysis of knockout mice has led to many discoveries about the functions of different Polycomb proteins in 
Table 1 Components of Polycomb repressive complexes and their hematopoietic phenotypes

\begin{tabular}{|c|c|c|c|c|}
\hline Complex & Gene & Expression alteration & Hematopoietic phenotype in mice & References \\
\hline \multirow[t]{7}{*}{$\mathrm{PRC} 1$} & \multirow[t]{2}{*}{ Bmi1 } & Knockout & $\begin{array}{l}\text { Postnatal pancytopenia due to impaired HSC self-renewal, hypoplasia of } \\
\text { spleen and thymus, maturation arrest in T and B cell development }\end{array}$ & {$[29-31,35,42]$} \\
\hline & & Overexpression & Enhanced HSC self-renewal & [31] \\
\hline & Mel18 & Knockout & $\begin{array}{l}\text { Hypoplasia of spleen and thymus, maturation arrest in T and B-cell develop- } \\
\text { ment }\end{array}$ & {$[31,37,42]$} \\
\hline & Rae28 & Knockout & $\begin{array}{l}\text { Decreased fetal liver HSCs, hypoplasia of spleen and thymus, maturation arrest } \\
\text { in B-cell development }\end{array}$ & {$[39,40,42]$} \\
\hline & $\mathrm{Cbx} 2$ & Knockout & $\begin{array}{l}\text { No effect on HSC activity, hypoplasia of spleen and thymus, maturation arrest } \\
\text { in T cell development }\end{array}$ & {$[31,41,42]$} \\
\hline & $\mathrm{Cbx} 8$ & Knockout & No effect on HSC activity & [43] \\
\hline & Ring1B & Knockout & Bone marrow hypocellularity and enlarged immature cell compartments & [44] \\
\hline \multirow[t]{5}{*}{ PRC2 } & Ezh1 & Knockout & $\begin{array}{l}\text { Significant loss of BM HSCs due to impaired self-renewal capacity, maturation } \\
\text { arrest in B cell development }\end{array}$ & {$[51]$} \\
\hline & \multirow[t]{2}{*}{ Ezh2 } & Knockout & $\begin{array}{l}\text { Embryonic lethality with anemia due to insufficient expansion of HSCs and } \\
\text { defective erythropoiesis in fetal liver, maturation arrest in T and B cell devel- } \\
\text { opment }\end{array}$ & {$[48-50]$} \\
\hline & & Knock-in/Overexpression & Enhanced HSC activity & {$[46,47]$} \\
\hline & Eed & Knockout & $\begin{array}{l}\text { HSC exhaustion in adult BM, defect in differentiation of HSCs into restricted } \\
\text { lineage progenitor cells }\end{array}$ & {$[52]$} \\
\hline & Suz12 & Knockout & $\begin{array}{l}\text { Loss of maintenance of HSCs in fetal liver and BM, maturation arrest in T and } \\
\mathrm{B} \text { cell development }\end{array}$ & {$[53]$} \\
\hline
\end{tabular}

HSCs (Table 1). The PRC1 subunit Bmil is expressed by HSCs and is essential for self-renewal of HSCs. HSCs in Bmil knockout mice lack the ability to self-renew, which causes progressive decline in HSCs after birth that leads to death from pancytopenia within 2 months. Transplanted fetal liver HSCs from $\mathrm{Bmi1}^{-1-}$ mice lose their long-term repopulating activity [29, 30]. In contrast, overexpression of Bmil in HSCs increases the number of HSCs by accelerating their self-renewal and increases their repopulating activity on transplantation [31]. One mechanism involved in the maintenance of HSC self-renewal by Bmi1 is regulation of expression at the INK4a/Arf locus. This locus encodes $\mathrm{p} 16^{\mathrm{INK} 4 \mathrm{a}}$ and $\mathrm{p} 19^{\mathrm{Arf}}$, two genes that repress the cell cycle. Expression of these genes is markedly enhanced in Bmi1 ${ }^{-1-}$ HSCs [32]. Bmi1 ${ }^{-1-}$ HSCs deficient for these genes partially recover their ability to proliferate. This indicates that the loss of the ability of HSCs to self-renew due to Bmi1 deficiency is at least partially attributable to derepression of expression of $\mathrm{p} 16^{\mathrm{INK} 4 \mathrm{a}}$ and $\mathrm{p} 19^{\text {Arf }}$ and the associated arrest of the cell cycle [33]. However, the discovery of the novel Bmil-binding protein UBAP2L, which regulates HSC activity without repressing the INK4a/Arf locus, suggests the existence of mechanisms independent of INK4a/Arf [34]. Bmil has been found to be an important factor in not only self-renewal but also pluripotency of HSCs [35]. In HSCs, the genes Ebf1 and Pax5, which regulate the development of $\mathrm{B}$-lineage cells, are repressed through bivalent domains. Bmil deficiency derepresses the expression of these genes and promotes differentiation into B-lineage cells. Therefore, Bmi1 suppresses lineage commitment by stabilizing bivalent domains at the loci of genes that regulate differentiation.

Although Bmi1 and Mel-18 are both members of the PCGF family and their amino acid sequences are highly homologous, Mel-18 has different functions in HSCs. Whereas $\mathrm{Bmil}^{-1-}$ fetal liver cells completely lack HSC activity, Mel-18 ${ }^{-/-}$fetal liver cells exhibit almost normal repopulating capacity [31]. It has even been found that Mel-18 $18^{-1}$ BM cells have a slightly enhanced ability to self-renew [36]. These findings indicate that Mel-18 is not essential in the function of HSCs. However, development of lymphoid cells is markedly disrupted in Mel-18 ${ }^{-1-}$ mice, which suggests that Mel-18 functions in differentiated cells rather than HSCs [37]. These differences in function between Bmil and Mel-18 also correspond to differences in their endogenous gene expression patterns, namely, that Bmi1 is expressed in undifferentiated hematopoietic cells whereas expression of Mel-18 increases with cellular differentiation [38].

The number of HSCs in Rae28-deficient mice progressively decreases during the embryonic stage. Whereas 1 in 20,000 wild type E14.5 fetal liver HSCs exhibits long-term repopulating activity, only 1 in 400,000 Rae $28^{-1-}$ HSCs does so. Transplantation of a Rae $28^{-1-}$ fetal liver into a lethally irradiated mouse reduces the number of HSCs and cells of each lineage in bone marrow (BM), which indicates 
that Rae28 is important in the maintenance of HSC activity $[39,40]$.

Fetal liver HSCs of mice deficient for Cbx2, a member of the CBX family, do not exhibit any obvious abnormalities and their number and repopulating ability are comparable to those of wild-type mice $[31,41]$. However, as with mice deficient for Bmi1, Mel-18, and Rae28, these mice exhibit hypoplasia of the thymus and spleen, and maturation arrest in lymphoid cell development [42]. In addition, the number of BM HSCs and their activity were found to be unaffected in Cbx8 knockout mice [43].

Ring1B, the catalytic subunit of PRC1, has been shown to serve different functions in different stages of differentiation of hematopoietic cells. Ring1B limits the proliferation of hematopoietic progenitor cells while promoting proliferation of maturing progeny by changing the expression patterns of $\mathrm{p} 16^{\mathrm{INK} 4 \mathrm{a}}$ and cyclin D2 [44]. Research has shown that Ring1A/B double-knockout ES cells cannot maintain their pluripotent status [45].

\section{PRC2 members in hematopoietic stem cells}

Ezh2, the catalytic subunit of PRC2, has been shown to enhance the proliferative capacity of HSCs in analysis of conditional knock-in mice [46]. In addition, although serial transplantation of hematopoietic cells into mice reduces repopulating activity, HSC exhaustion can be completely prevented by overexpression of Ezh2 [47]. Fetal livers of Ezh2-deficient mice have a lower number of HSCs and defective erythropoiesis, which lead to fetal death from anemia. However, adult BM cells of Ezh2 conditional knockout mice only exhibit maturation arrest in $\mathrm{T}$ and $\mathrm{B}$ cell development, without any obvious impact on HSC function [48-50]. The H3K27me3 level is lower in fetal liver cells of Ezh2-deficient mice, but is almost normal in adult BM. This suggests that the level is supplemented by the homolog Ezh1 in adult BM HSCs. Actually, whereas Ezh2 is expressed ubiquitously, Ezh1 expression is much

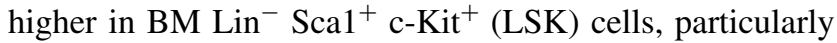
HSCs, than fetal liver LSK cells, a finding that supports that Ezh1 functions in BM HSCs [48]. Recent research involving analysis of Ezh1-deficient mice has also demonstrated the importance of Ezh1 in BM HSCs. Fetal livers of Ezh1-deficient mice have a slightly lower number of HSCs, but no issues with maintenance of fetal hematopoiesis. In BM, however, Ezh1 deficiency causes a strong senescence response, leading to marked loss of HSCs through disruption of their ability to self-renew. Decreases in the B cell population and shrinking of the spleen are also observed. Simultaneous loss of Ezh1 and Ink4a causes HSCs to regain their ability to proliferate and survive, which indicates that Ezh1 maintains adult BM HSCs by repressing Ink4a [51].
Newborn mice with blood cell-specific EED deficiency exhibit leukopenia, anemia, and shrinkage of the spleen, which indicates that Eed is essential in normal hematopoiesis. Long-term (LT) HSCs lose their ability to differentiate, which impedes the differentiation of HSCs into lineagerestricted progenitor cells. Although a decrease in B cells is observed in embryos, there are no obvious changes in the number or percentage of fetal liver HSCs. The above findings illustrate that Eed is necessary for the function of adult HSCs rather than fetal HSCs [52].

Recent research involving analysis of Suz12 conditional knockout mice has shown Suz12 to be essential in the maintenance of both adult and embryonic HSCs. Loss of Suz12 causes HSCs to lose their ability to self-renew and exhausts the HSC pool. Additionally, although Suz12 is essential in lymphocyte formation, it is not necessary for differentiation of myeloid and megakaryocytic cells [53].

In summary, many discoveries have been made by analyzing the function of different PRC1/2 members in HSCs, from the perspective of gains and losses of function. However, these components can be combined in diverse patterns, and the impact of differences in pattern on the function of complexes remains unknown.

\section{The roles of Polycomb group proteins in hematological malignancies}

It is believed that not only gene mutations and genomic abnormalities but also abnormalities in epigenetic regulatory mechanisms such as DNA methylation and histone modification are involved in carcinogenesis. Many different expression level abnormalities and mutations in PcG genes involved in epigenetic regulation have been reported in various types of cancer including hematological malignancies $[54,55]$. This indicates that the breakdown of regulation of expression by PRC1/2 can cause carcinogenesis. This section will cover abnormalities in PcG proteins that have been observed in various types of hematological malignancies (Table 2) and their functions as discovered through experiments in mice.

\section{PRC1 members in hematological malignancies}

Bmil came to be recognized as a gene involved in carcinogenesis after its isolation as a gene that cooperates with c-myc in the development of lymphomas [56]. High expression of Bmil has so far been observed in myelodysplastic syndrome (MDS) [57, 58], acute myeloid leukemia (AML) [59, 60], chronic myeloid leukemia (CML) [61, 62], and various types of lymphoma including diffuse large B cell lymphoma (DLBCL) [63-66], and has been shown to be correlated with poor prognosis. Recently, IG-BMI1 
Table 2 Components of Polycomb repressive complexes and their alterations in hematological malignancies

\begin{tabular}{|c|c|c|c|c|}
\hline Complex & Gene & Types of hematological malignancies & Aberration & References \\
\hline \multirow[t]{6}{*}{ PRC1 } & \multirow[t]{3}{*}{ Bmi1 } & MDS, AML, CML & Overexpression & {$[57-62]$} \\
\hline & & HRS, B-NHLs & Overexpression & [63-66] \\
\hline & & B-CLL & IG-BMI1 fusion & [67] \\
\hline & $\operatorname{Cbx} 7$ & FL & Overexpression & {$[72]$} \\
\hline & \multirow[t]{2}{*}{ Ring1A } & MDS, AML & Overexpression & {$[58]$} \\
\hline & & NHLs & SNPs (rs2855429, rs213213) & {$[73]$} \\
\hline \multirow[t]{9}{*}{ PRC2 } & \multirow[t]{5}{*}{ Ezh2 } & MDS, AML & Overexpression & {$[58]$} \\
\hline & & HRS, B-NHLs, ATL & Overexpression & {$[63,64,74,75]$} \\
\hline & & FL, DLBCL & Gain-of-function mutation (Tyr641, Ala677) & {$[76-78]$} \\
\hline & & T-ALL, ETP-ALL & Loss-of-function mutation/deletion & {$[79,80]$} \\
\hline & & MDS, MDS/MPN, MF & Loss-of-function mutation/deletion & {$[81,82]$} \\
\hline & \multirow[t]{2}{*}{ Eed } & ETP-ALL & Loss-of-function mutation/deletion & {$[80]$} \\
\hline & & MDS/MPN & Loss-of-function mutation & {$[83]$} \\
\hline & \multirow[t]{2}{*}{ Suz12 } & T-ALL, ETP-ALL & Loss-of-function mutation/deletion & {$[79,80]$} \\
\hline & & MDS/MPN & Loss-of-function mutation & {$[83]$} \\
\hline
\end{tabular}

$A M L$ acute myeloid leukemia, $A T L$ adult Tcell leukemia/lymphoma, $B$-CLL B cell chronic lymphocytic leukemia, $B$ - $N H L s$ B cell non-Hodgkin lymphomas, $C M L$ chronic myeloid leukemia, $D L B C L$ diffuse large B-cell lymphoma, ETP-ALL early T-cell precursor acute lymphoblastic leukemia, $F L$ follicular lymphomas, $H R S$ Reed-Sternberg cells of Hodgkin's disease, $M D S$ myelodysplastic syndromes, $M D S / M P N$ myelodysplastic syndrome/myeloproliferative neoplasms; MF, myelofibrosis; NHLs, non-Hodgkin lymphomas; T-ALL, T-cell acute lymphoblastic leukemia

has been identified as a new fusion gene that is acquired in the advanced stage of chronic lymphocytic leukemia (CLL) and up-regulates expression of Bmi1 [67].

Multiple experiments in mouse models have shown that Bmil is involved in leukemogenesis and the maintenance of leukemia stem cells (LSCs). The MLL-AF9 fusion gene immortalizes granulocyte/macrophage progenitors (GMPs) and induces the onset of AML when transplanted into irradiated mice, but AML cannot be induced by MLL-AF9 using GMPs derived from Bmi1-deficient mice [68]. It is also not possible to use hematopoietic progenitor cells derived from Bmi1-deficient mice in transformation of hematopoietic progenitor cells by the E2a-Pbx 1 fusion gene frequently detected in pre-B lymphoblastic leukemia. Transformation by $\mathrm{E} 2 \mathrm{a}-\mathrm{Pbx} 1$ is possible in mice deficient for both Bmil and Ink4a-Arf, which indicates that increased expression of Ink4a-Arf is why transformation cannot be achieved with progenitor cells from Bmildeficient mice [69]. These results indicate that Bmil is an important factor in leukemic transformation. HoxA9 and Meis1 are other oncogenes that can induce the transformation of mouse BM cells. However, when $\mathrm{Bmi}^{-1-}$ fetal liver cells forced to express these genes are transplanted into irradiated mice, they can only induce AML in primary transplantation and not in secondary transplantation [29]. These results indicate that Bmil is essential in the maintenance of repopulating LSCs in mice.

Results of many studies suggest that Bmil is also involved in the progression of CML. The expression level of Bmil is higher in advanced-phase patients than in chronic-phase patients, with the expression level at diagnosis correlating with time until transformation to blast crisis [61]. Overexpression of BMI1 in CD34 ${ }^{+}$cells derived from CML patients enhances their proliferative activity and selfrenewal properties in vitro, and also enhances the potential for leukemic transformation when transplanted into immunodeficient mice [70]. These results suggest that Bmi1 may collaborate with BCR-ABL in the malignant transformation of leukemia cells. The synergistic effects of Bmil and BCR-ABL have also been observed in mouse models of B-progenitor acute lymphoblastic leukemia (B-ALL) initiation from CML B lymphoid progenitors [71].

High expression of $\mathrm{Cbx} 7$ has been found in follicular lymphoma. When expression of $\mathrm{Cbx} 7$ was forced in HSCs in an in vivo experiment, $\mathrm{Cbx} 7$ cooperated with c-myc to produce T-cell and B-cell lymphomas [72]. Cbx8 has been shown to be essential in the onset of MLL-AF9-induced leukemogenesis in AML. Cbx8 binds to MLL-AF9, and it is possible to prevent MLL-AF9-induced transformation by inhibiting that binding with point mutations or knockdown of Cbx8 [43].

High expression of Ring1A has been observed in MDS and AML and has been shown to be related to poor prognosis [58]. Additionally, SNPs in Ring1A have been found to be strongly associated with risk for non-Hodgkin lymphoma [73].

Although many such discoveries have been made about the functions of constituent factors of PRC1 in 
hematological malignancies, it is not known how Ring1A and Ring1B, which form the active center of PRC1, function in hematological malignancies. Therefore, we performed an experiment to determine the functions of Ring1A and Ring1B in AML. We investigated if irradiated wildtype mice would develop AML, when administered tamoxifen (or a control of corn oil) after transplantation of $\mathrm{cKit}^{+}$ BM-derived cells from Ring1A/B double-knockout mice (Ring1 $\mathrm{A}^{-/-}$, Ring1B ${ }^{\mathrm{F} / \mathrm{F}}$, CreETR2), into which MOZ-TIF2 or MLL-AF10 had been introduced. We found that whereas all mice in the control group developed AML and died, all mice in the group administered tamoxifen survived. When we analyzed leukemia cells after administering tamoxifen, we found that the LSC fraction had decreased, differentiation had been induced, and AML did not repopulate when cells were re-transplanted into other mice. These results indicate that Ring1A and Ring1B are essential in the onset of AML induced by MOZ-TIF2 and MLL-AF10, and in the maintenance of LSCs (manuscript in preparation).

\section{PRC2 members in hematological malignancies}

High Ezh2 expression has been observed in MDS, AML, and B-cell and T-cell lymphomas [58, 63, 64, 74, 75]. In addition, mutation in tyrosine residue 641 of the SET domain, which is the catalytic site of Ezh2, is detected in $7.2 \%$ of patients with follicular lymphoma (FL) and $21.7 \%$ of patients with DLBCL [76]. Mutants with this gain-of-function mutation have been found to have higher di- and tri-methylation of $\mathrm{H} 3 \mathrm{~K} 27$ than the wild type [77]. Mutation in alanine residue 677 has also been reported as a similar functional mutation in DLBCL [78]. The results of these studies suggest that up-regulation of Ezh2 contributes to tumorigenesis and thus, Ezh2 functions as an oncogene.

Conversely, loss-of-function mutations in Ezh2 and other constituent factors of PRC2 as well as loss of these genes have also been reported in various hematological malignancies, which indicates that Ezh2 also serves as a tumor suppressor gene. Loss-of-function mutations or deletions in Ezh2 or Suz12 have been detected in a respective 18 and $7 \%$ of patients with T-cell acute lymphoblastic leukemia (T-ALL) [79]. Loss of Ezh2, EED, or Suz12 or sequence mutations in any of these genes have been detected in $42.2 \%$ of patients with early T-cell precursor acute lymphoblastic leukemia (ETP-ALL) [80]. Various homozygous and heterozygous loss-of-function mutations in Ezh2 have also been observed in MDS, MDS/myeloproliferative neoplasms (MPN), and myelofibrosis [81, 82]. Loss-of-function mutations in Suz12 and EED have also been detected in MDS/MPN, though they are infrequent [83]. These findings suggest that functional inhibition of PRC2 may promote tumor formation.
In summary, Ezh2 plays dual roles in the process of carcinogenesis, functioning as both an oncogene and a tumor suppressor gene. This functional duality of Ezh2 has also been demonstrated in experiments in mouse models. Several experiments in which mice were observed long-term after loss of Ezh2 in hematopoietic cells showed that this loss leads to development of heterogeneous malignancies including T-ALL, MDS, and MDS/MPN [84-86]. These results indicate that Ezh2 functions as a tumor suppressor gene in the pathogenesis of T-ALL and MDS-related diseases. Ezh2 has also been found to play an oncogenic role in lymphoma and AML. A recent study showed that Ezh2 ${ }^{\mathrm{Y} 641 \mathrm{~F}}$, which is detected as a gain-of-function mutation in FL and DLBCL, strongly promotes the development of lymphoma in mice by collaborating with c-Myc [87]. Ezh2 is believed to be important in leukemogenesis because, loss of Ezh2 decreases the proliferative ability of leukemia cells and induces differentiation, delaying the onset of AML induced by the MLL-AF9 fusion gene in mice [88, 89].

\section{Targeted therapy against Polycomb members}

As discussed in the previous sections, abnormalities related to PcG proteins, including abnormal expression levels and mutations, have been observed in specimens from various types of hematological malignancies, and the dependency of these malignancies on Polycomb proteins has been demonstrated in mouse models. These findings have sparked an increasing interest in PcG proteins as therapeutic targets in recent years. Actually, several research groups have discovered low molecular weight compounds that inhibit the enzymatic activity of Ezh2 and show a strong antitumor effect in cell lines and xenograft models of lymphoma with gain-of-function mutations in Ezh2 [90-92]. Another compound that was discovered is stabilized $\alpha$-helix of EZH2 peptide (SAH-EZH2), which decreases the H3K27me3 level by inhibiting binding of Ezh2 and EED. Treatment of MLL-AF9 leukemia cells with SAH-EZH2 arrests proliferation and induces monocyte-macrophage differentiation, which suggests that drugs that inhibit Ezh2 are effective against AML that is dependent on Ezh2 expression [93].

\section{Concluding remarks}

This paper covered the functions of PcG proteins in normal hematopoiesis and in various hematological malignancies. PcG proteins play a major role in the maintenance of normal HSCs. Depending on the type of hematopoietic malignancy, they can function as oncogenes, tumor suppressor genes, or even both. The functions of PcG proteins differ not only between hematological malignancies but 
also between various solid tumors, and various PcG protein abnormalities such as overexpression, decreased expression, and mutation are observed. Ezh2 inhibitors have been found effective against lymphoma and AML, cancers in which Ezh2 has been experimentally demonstrated to act as an oncogene. This indicates that it is important to understand how PcG proteins function in different types of cancer. Hopefully, effective treatments against various diseases will be developed as more information about mechanisms of $\mathrm{PcG}$ protein involvement in carcinogenesis is uncovered.

\section{References}

1. Jaenisch R, Bird A. Epigenetic regulation of gene expression: how the genome integrates intrinsic and environmental signals. Nat Genet. 2003;33(Suppl):245-54.

2. Lund AH, van Lohuizen M. Epigenetics and cancer. Genes Dev. 2004;18(19):2315-35.

3. Sparmann A, van Lohuizen M. Polycomb silencers control cell fate, development and cancer. Nat Rev Cancer. 2006;6(11):846-56.

4. Pietersen AM, van Lohuizen M. Stem cell regulation by polycomb repressors: postponing commitment. Curr Opin Cell Biol. 2008;20(2):201-7.

5. Oshima M, Iwama A. Epigenetics of hematopoietic stem cell aging and disease. Int J Hematol. 2014;100(4):326-34.

6. Lewis EB. A gene complex controlling segmentation in Drosophila. Nature. 1978;276(5688):565-70.

7. Cao R, Wang L, Wang H, Xia L, Erdjument-Bromage H, Tempst $\mathrm{P}$, et al. Role of histone H3 lysine 27 methylation in Polycombgroup silencing. Science N Y NY. 2002;298(5595):1039-43.

8. Czermin B, Melfi R, McCabe D, Seitz V, Imhof A, Pirrotta V. Drosophila enhancer of Zeste/ESC complexes have a histone H3 methyltransferase activity that marks chromosomal Polycomb sites. Cell. 2002;111(2):185-96.

9. Margueron R, Justin N, Ohno K, Sharpe ML, Son J, Drury WJ, et al. Role of the polycomb protein EED in the propagation of repressive histone marks. Nature. 2009;461(7265):762-7.

10. Cao R, Zhang Y. SUZ12 is required for both the histone methyltransferase activity and the silencing function of the EED-EZH2 complex. Mol Cell. 2004;15(1):57-67.

11. Wang H, Wang L, Erdjument-Bromage H, Vidal M, Tempst P, Jones RS, et al. Role of histone H2A ubiquitination in Polycomb silencing. Nature. 2004;431(7010):873-8.

12. Fischle W, Wang Y, Jacobs SA, Kim Y, Allis CD, Khorasanizadeh S. Molecular basis for the discrimination of repressive methyl-lysine marks in histone H3 by Polycomb and HP1 chromodomains. Genes Dev. 2003;17(15):1870-81.

13. Buchwald G, van der Stoop P, Weichenrieder O, Perrakis A, van Lohuizen M, Sixma TK. Structure and E3-ligase activity of the Ring-Ring complex of polycomb proteins Bmi1 and Ring1b. EMBO J. 2006;25(11):2465-74.

14. Stock JK, Giadrossi S, Casanova M, Brookes E, Vidal M, Koseki $\mathrm{H}$, et al. Ring1-mediated ubiquitination of $\mathrm{H} 2 \mathrm{~A}$ restrains poised RNA polymerase II at bivalent genes in mouse ES cells. Nat Cell Biol. 2007;9(12):1428-35.

15. Francis NJ, Kingston RE, Woodcock CL. Chromatin compaction by a polycomb group protein complex. Science N Y NY. 2004;306(5701):1574-7.

16. Morey L, Aloia L, Cozzuto L, Benitah SA, Di Croce L. RYBP and $\mathrm{Cbx} 7$ define specific biological functions of polycomb complexes in mouse embryonic stem cells. Cell Rep. 2013;3(1):60-9.

17. Gao Z, Zhang J, Bonasio R, Strino F, Sawai A, Parisi F, et al. PCGF homologs, CBX proteins, and RYBP define functionally distinct PRC1 family complexes. Mol Cell. 2012;45(3):344-56.

18. Tavares L, Dimitrova E, Oxley D, Webster J, Poot R, Demmers $\mathrm{J}$, et al. RYBP-PRC1 complexes mediate $\mathrm{H} 2 \mathrm{~A}$ ubiquitylation at polycomb target sites independently of PRC2 and H3K27me3. Cell. 2012;148(4):664-78.

19. Blackledge NP, Farcas AM, Kondo T, King HW, McGouran JF, Hanssen LL, et al. Variant PRC1 complex-dependent H2A ubiquitylation drives $\mathrm{PRC} 2$ recruitment and polycomb domain formation. Cell. 2014;157(6):1445-59.

20. Kalb R, Latwiel S, Baymaz HI, Jansen PW, Muller CW, Vermeulen $\mathrm{M}$, et al. Histone $\mathrm{H} 2 \mathrm{~A}$ monoubiquitination promotes histone H3 methylation in Polycomb repression. Nat Struct Mol Biol. 2014;21(6):569-71.

21. Sing A, Pannell D, Karaiskakis A, Sturgeon K, Djabali M, Ellis $\mathrm{J}$, et al. A vertebrate Polycomb response element governs segmentation of the posterior hindbrain. Cell. 2009;138(5):885-97.

22. Ku M, Koche RP, Rheinbay E, Mendenhall EM, Endoh M, Mikkelsen TS, et al. Genomewide analysis of PRC1 and PRC2 occupancy identifies two classes of bivalent domains. PLoS Genet. 2008;4(10):e1000242.

23. Ross J, Mavoungou L, Bresnick EH, Milot E. GATA-1 utilizes Ikaros and polycomb repressive complex 2 to suppress Hes1 and to promote erythropoiesis. Mol Cell Biol. 2012;32(18):3624-38.

24. Boulay G, Dubuissez M, Van Rechem C, Forget A, Helin K, Ayrault $\mathrm{O}$, et al. Hypermethylated in cancer 1 (HIC1) recruits polycomb repressive complex 2 (PRC2) to a subset of its target genes through interaction with human polycomb-like (hPCL) proteins. J Biol Chem. 2012;287(13):10509-24.

25. Dietrich N, Lerdrup M, Landt E, Agrawal-Singh S, Bak M, Tommerup N, et al. REST-mediated recruitment of polycomb repressor complexes in mammalian cells. PLoS Genet. 2012;8(3):e1002494.

26. Yu M, Mazor T, Huang H, Huang HT, Kathrein KL, Woo AJ, et al. Direct recruitment of polycomb repressive complex 1 to chromatin by core binding transcription factors. Mol Cell. 2012;45(3):330-43.

27. Peschansky VJ, Wahlestedt C. Non-coding RNAs as direct and indirect modulators of epigenetic regulation. Epigenetics. 2014;9(1):3-12.

28. Cui K, Zang C, Roh TY, Schones DE, Childs RW, Peng W, et al. Chromatin signatures in multipotent human hematopoietic stem cells indicate the fate of bivalent genes during differentiation. Cell Stem Cell. 2009;4(1):80-93.

29. Lessard J, Sauvageau G. Bmi-1 determines the proliferative capacity of normal and leukaemic stem cells. Nature. 2003;423(6937):255-60.

30. Park IK, Qian D, Kiel M, Becker MW, Pihalja M, Weissman IL, et al. Bmi-1 is required for maintenance of adult self-renewing haematopoietic stem cells. Nature. 2003;423(6937):302-5.

31. Iwama A, Oguro H, Negishi M, Kato Y, Morita Y, Tsukui $\mathrm{H}$, et al. Enhanced self-renewal of hematopoietic stem cells mediated by the polycomb gene product Bmi-1. Immunity. 2004;21(6):843-51.

32. Jacobs JJ, Scheijen B, Voncken JW, Kieboom K, Berns A, van Lohuizen M. Bmi-1 collaborates with c-Myc in tumorigenesis by inhibiting c-Myc-induced apoptosis via INK4a/ARF. Genes Dev. 1999;13(20):2678-90.

33. Oguro $H$, Iwama A, Morita $Y$, Kamijo $T$, van Lohuizen $M$, Nakauchi H. Differential impact of Ink4a and Arf on hematopoietic stem cells and their bone marrow microenvironment in Bmi1-deficient mice. J Exp Med. 2006;203(10):2247-53. 
34. Bordeleau ME, Aucagne R, Chagraoui J, Girard S, Mayotte N, Bonneil E, et al. UBAP2L is a novel BMI1-interacting protein essential for hematopoietic stem cell activity. Blood. 2014;124(15):2362-9.

35. Oguro H, Yuan J, Ichikawa H, Ikawa T, Yamazaki S, Kawamoto $\mathrm{H}$, et al. Poised lineage specification in multipotential hematopoietic stem and progenitor cells by the polycomb protein Bmil. Cell Stem Cell. 2010;6(3):279-86.

36. Kajiume T, Ninomiya Y, Ishihara H, Kanno R, Kanno M. Polycomb group gene mel-18 modulates the self-renewal activity and cell cycle status of hematopoietic stem cells. Exp Hematol. 2004;32(6):571-8.

37. Akasaka T, Tsuji K, Kawahira H, Kanno M, Harigaya K, Hu L, et al. The role of mel-18, a mammalian Polycomb group gene, during IL-7-dependent proliferation of lymphocyte precursors. Immunity. 1997;7(1):135-46.

38. Lessard J, Baban S, Sauvageau G. Stage-specific expression of polycomb group genes in human bone marrow cells. Blood. 1998;91(4):1216-24.

39. Ohta H, Sawada A, Kim JY, Tokimasa S, Nishiguchi S, Humphries RK, et al. Polycomb group gene rae28 is required for sustaining activity of hematopoietic stem cells. J Exp Med. 2002;195(6):759-70.

40. Kim JY, Sawada A, Tokimasa S, Endo H, Ozono K, Hara J, et al. Defective long-term repopulating ability in hematopoietic stem cells lacking the Polycomb-group gene rae28. Eur J Haematol. 2004;73(2):75-84

41. Core N, Bel S, Gaunt SJ, Aurrand-Lions M, Pearce J, Fisher $\mathrm{A}$, et al. Altered cellular proliferation and mesoderm patterning in Polycomb-M33-deficient mice. Dev Camb Engl. 1997;124(3):721-9.

42. Raaphorst FM, Otte AP, Meijer CJ. Polycomb-group genes as regulators of mammalian lymphopoiesis. Trends Immunol. 2001;22(12):682-90.

43. Tan J, Jones M, Koseki H, Nakayama M, Muntean AG, Maillard I, et al. CBX8, a polycomb group protein, is essential for MLLAF9-induced leukemogenesis. Cancer Cell. 2011;20(5):563-75.

44. Cales C, Roman-Trufero M, Pavon L, Serrano I, Melgar T, Endoh $\mathrm{M}$, et al. Inactivation of the polycomb group protein Ring1B unveils an antiproliferative role in hematopoietic cell expansion and cooperation with tumorigenesis associated with Ink4a deletion. Mol Cell Biol. 2008;28(3):1018-28.

45. Endoh M, Endo TA, Endoh T, Fujimura Y, Ohara O, Toyoda T, et al. Polycomb group proteins Ring1A/B are functionally linked to the core transcriptional regulatory circuitry to maintain ES cell identity. Dev Camb Engl. 2008;135(8):1513-24.

46. Herrera-Merchan A, Arranz L, Ligos JM, de Molina A, Dominguez O, Gonzalez S. Ectopic expression of the histone methyltransferase Ezh2 in haematopoietic stem cells causes myeloproliferative disease. Nat Commun. 2012;3:623.

47. Kamminga LM, Bystrykh LV, de Boer A, Houwer S, Douma $\mathrm{J}$, Weersing E, et al. The Polycomb group gene Ezh2 prevents hematopoietic stem cell exhaustion. Blood. 2006;107(5):2170-9.

48. Mochizuki-Kashio M, Mishima Y, Miyagi S, Negishi M, Saraya A, Konuma T, et al. Dependency on the polycomb gene Ezh2 distinguishes fetal from adult hematopoietic stem cells. Blood. 2011;118(25):6553-61.

49. O'Carroll D, Erhardt S, Pagani M, Barton SC, Surani MA, Jenuwein T. The polycomb-group gene Ezh2 is required for early mouse development. Mol Cell Biol. 2001;21(13):4330-6.

50. Su IH, Basavaraj A, Krutchinsky AN, Hobert O, Ullrich A, Chait BT, et al. Ezh2 controls B cell development through histone $\mathrm{H} 3$ methylation and Igh rearrangement. Nat Immunol. 2003;4(2):124-31

51. Hidalgo I, Herrera-Merchan A, Ligos JM, Carramolino L, Nunez $\mathrm{J}$, Martinez F, et al. Ezh1 is required for hematopoietic stem cell maintenance and prevents senescence-like cell cycle arrest. Cell Stem Cell. 2012;11(5):649-62.

52. Xie H, Xu J, Hsu JH, Nguyen M, Fujiwara Y, Peng C, et al. Polycomb repressive complex 2 regulates normal hematopoietic stem cell function in a developmental-stage-specific manner. Cell Stem Cell. 2014;14(1):68-80.

53. Lee SC, Miller S, Hyland C, Kauppi M, Lebois M, Di Rago $\mathrm{L}$, et al. Polycomb repressive complex 2 component Suz12 is required for hematopoietic stem cell function and lymphopoiesis. Blood. 2015;126(2):167-75.

54. Martin-Perez D, Piris MA, Sanchez-Beato M. Polycomb proteins in hematologic malignancies. Blood. 2010;116(25):5465-75.

55. Sauvageau M, Sauvageau G. Polycomb group proteins: multifaceted regulators of somatic stem cells and cancer. Cell Stem Cell. 2010;7(3):299-313.

56. van Lohuizen M, Verbeek S, Scheijen B, Wientjens E, van der Gulden H, Berns A. Identification of cooperating oncogenes in E mu-myc transgenic mice by provirus tagging. Cell. 1991;65(5):737-52.

57. Mihara K, Chowdhury M, Nakaju N, Hidani S, Ihara A, Hyodo $\mathrm{H}$, et al. Bmi-1 is useful as a novel molecular marker for predicting progression of myelodysplastic syndrome and patient prognosis. Blood. 2006;107(1):305-8.

58. Xu F, Li X, Wu L, Zhang Q, Yang R, Yang Y, et al. Overexpression of the EZH2, RING1 and BMI1 genes is common in myelodysplastic syndromes: relation to adverse epigenetic alteration and poor prognostic scoring. Ann Hematol. 2011;90(6):643-53.

59. Chowdhury M, Mihara K, Yasunaga S, Ohtaki M, Takihara Y, Kimura A. Expression of Polycomb-group (PcG) protein BMI-1 predicts prognosis in patients with acute myeloid leukemia. Leukemia. 2007;21(5):1116-22.

60. Saudy NS, Fawzy IM, Azmy E, Goda EF, Eneen A, Abdul Salam EM. BMI1 gene expression in myeloid leukemias and its impact on prognosis. Blood Cells Mol Dis. 2014;53(4):194-8.

61. Mohty M, Yong AS, Szydlo RM, Apperley JF, Melo JV. The polycomb group BMI1 gene is a molecular marker for predicting prognosis of chronic myeloid leukemia. Blood. 2007;110(1):380-3.

62. Yong AS, Stephens N, Weber G, Li Y, Savani BN, Eniafe R, et al. Improved outcome following allogeneic stem cell transplantation in chronic myeloid leukemia is associated with higher expression of BMI-1 and immune responses to BMI-1 protein. Leukemia. 2011;25(4):629-37.

63. Raaphorst FM, van Kemenade FJ, Blokzijl T, Fieret E, Hamer KM, Satijn DPE, et al. Coexpression of BMI-1 and EZH2 polycomb group genes in reed-sternberg cells of Hodgkin's disease. Am J Pathol. 2000;157(3):709-15.

64. van Kemenade FJ, Raaphorst FM, Blokzijl T, Fieret E, Hamer KM, Satijn DP, et al. Coexpression of BMI-1 and EZH2 polycomb-group proteins is associated with cycling cells and degree of malignancy in B-cell non-Hodgkin lymphoma. Blood. 2001;97(12):3896-901.

65. van Galen JC, Muris JJ, Oudejans JJ, Vos W, Giroth CP, Ossenkoppele GJ, et al. Expression of the polycomb-group gene BMI1 is related to an unfavourable prognosis in primary nodal DLBCL. J Clin Pathol. 2007;60(2):167-72.

66. Bea S, Tort F, Pinyol M, Puig X, Hernandez L, Hernandez S, et al. BMI-1 gene amplification and overexpression in hematological malignancies occur mainly in mantle cell lymphomas. Cancer Res. 2001;61(6):2409-12.

67. Rouhigharabaei L, Ferreiro JF, Put N, Michaux L, Tousseyn T, Lefebvre C, et al. BMI1, the polycomb-group gene, is recurrently targeted by genomic rearrangements in progressive B-cell leukemia/lymphoma. Genes Chromosom Cancer. 2013;52(10):928-44. 
68. Yuan J, Takeuchi M, Negishi M, Oguro H, Ichikawa H, Iwama A. Bmil is essential for leukemic reprogramming of myeloid progenitor cells. Leukemia. 2011;25(8):1335-43.

69. Smith KS, Chanda SK, Lingbeek M, Ross DT, Botstein D, van Lohuizen M, et al. Bmi-1 Regulation of INK4A-ARF is a downstream requirement for transformation of hematopoietic progenitors by E2a-Pbx1. Mol Cell. 2003;12(2):393-400.

70. Rizo A, Horton SJ, Olthof S, Dontje B, Ausema A, van Os R, et al. BMI1 collaborates with BCR-ABL in leukemic transformation of human CD34 + cells. Blood. 2010;116(22):4621-30.

71. Sengupta A, Ficker AM, Dunn SK, Madhu M, Cancelas JA. Bmi1 reprograms CML B-lymphoid progenitors to become B-ALL-initiating cells. Blood. 2012;119(2):494-502.

72. Scott CL, Gil J, Hernando E, Teruya-Feldstein J, Narita M, Martinez D, et al. Role of the chromobox protein CBX7 in lymphomagenesis. Proc Natl Acad Sci USA. 2007;104(13):5389-94.

73. Wang SS, Menashe I, Cerhan JR, Cozen W, Severson RK, Davis $\mathrm{S}$, et al. Variations in chromosomes 9 and $6 \mathrm{p} 21.3$ with risk of non-Hodgkin lymphoma. Cancer Epidemiol Biomark Prev. 2011;20(1):42-9.

74. Sasaki D, Imaizumi Y, Hasegawa H, Osaka A, Tsukasaki K, Choi YL, et al. Overexpression of Enhancer of zeste homolog 2 with trimethylation of lysine 27 on histone $\mathrm{H} 3$ in adult T-cell leukemia/lymphoma as a target for epigenetic therapy. Haematologica. 2011;96(5):712-9.

75. Visser HP, Gunster MJ, Kluin-Nelemans HC, Manders EM, Raaphorst FM, Meijer CJ, et al. The Polycomb group protein EZH2 is upregulated in proliferating, cultured human mantle cell lymphoma. Br J Haematol. 2001;112(4):950-8.

76. Morin RD, Johnson NA, Severson TM, Mungall AJ, An J, Goya $\mathrm{R}$, et al. Somatic mutations altering EZH2 (Tyr641) in follicular and diffuse large B-cell lymphomas of germinal-center origin. Nat Genet. 2010;42(2):181-5.

77. Sneeringer CJ, Scott MP, Kuntz KW, Knutson SK, Pollock RM, Richon VM, et al. Coordinated activities of wild-type plus mutant EZH2 drive tumor-associated hypertrimethylation of lysine 27 on histone H3 (H3K27) in human B-cell lymphomas. Proc Natl Acad Sci USA. 2010;107(49):20980-5.

78. McCabe MT, Graves AP, Ganji G, Diaz E, Halsey WS, Jiang $\mathrm{Y}$, et al. Mutation of A677 in histone methyltransferase EZH2 in human B-cell lymphoma promotes hypertrimethylation of histone H3 on lysine 27 (H3K27). Proc Natl Acad Sci USA. 2012;109(8):2989-94.

79. Ntziachristos P, Tsirigos A, Van Vlierberghe P, Nedjic J, Trimarchi T, Flaherty MS, et al. Genetic inactivation of the polycomb repressive complex 2 in $\mathrm{T}$ cell acute lymphoblastic leukemia. Nat Med. 2012;18(2):298-301.

80. Zhang J, Ding L, Holmfeldt L, Wu G, Heatley SL, Payne-Turner $\mathrm{D}$, et al. The genetic basis of early T-cell precursor acute lymphoblastic leukaemia. Nature. 2012;481(7380):157-63.
81. Ernst T, Chase AJ, Score J, Hidalgo-Curtis CE, Bryant C, Jones $\mathrm{AV}$, et al. Inactivating mutations of the histone methyltransferase gene EZH2 in myeloid disorders. Nat Genet. 2010;42(8):722-6.

82. Nikoloski G, Langemeijer SM, Kuiper RP, Knops R, Massop $\mathrm{M}$, Tonnissen ER, et al. Somatic mutations of the histone methyltransferase gene EZH2 in myelodysplastic syndromes. Nat Genet. 2010;42(8):665-7.

83. Score J, Hidalgo-Curtis C, Jones AV, Winkelmann N, Skinner $\mathrm{A}$, Ward D, et al. Inactivation of polycomb repressive complex 2 components in myeloproliferative and myelodysplastic/myeloproliferative neoplasms. Blood. 2012;119(5):1208-13.

84. Simon C, Chagraoui J, Krosl J, Gendron P, Wilhelm B, Lemieux S, et al. A key role for EZH2 and associated genes in mouse and human adult T-cell acute leukemia. Genes Dev. 2012;26(7):651-6.

85. Muto T, Sashida G, Oshima M, Wendt GR, Mochizuki-Kashio M, Nagata Y, et al. Concurrent loss of Ezh2 and Tet2 cooperates in the pathogenesis of myelodysplastic disorders. J Exp Med. 2013;210(12):2627-39.

86. Mochizuki-Kashio M, Aoyama K, Sashida G, Oshima M, Tomioka T, Muto T, et al. Ezh2 loss in hematopoietic stem cells predisposes mice to develop heterogeneous malignancies in an Ezh1-dependent manner. Blood. 2015;126(10):1172-83.

87. Berg T, Thoene S, Yap D, Wee T, Schoeler N, Rosten P, et al. A transgenic mouse model demonstrating the oncogenic role of mutations in the polycomb-group gene EZH2 in lymphomagenesis. Blood. 2014;123(25):3914-24.

88. Tanaka S, Miyagi S, Sashida G, Chiba T, Yuan J, MochizukiKashio M, et al. Ezh2 augments leukemogenicity by reinforcing differentiation blockage in acute myeloid leukemia. Blood. 2012;120(5):1107-17.

89. Neff T, Sinha AU, Kluk MJ, Zhu N, Khattab MH, Stein L, et al. Polycomb repressive complex 2 is required for MLL-AF9 leukemia. Proc Natl Acad Sci USA. 2012;109(13):5028-33.

90. McCabe MT, Ott HM, Ganji G, Korenchuk S, Thompson C, Van Aller GS, et al. EZH2 inhibition as a therapeutic strategy for lymphoma with EZH2-activating mutations. Nature. 2012;492(7427):108-12.

91. Campbell JE, Kuntz KW, Knutson SK, Warholic NM, Keilhack H, Wigle TJ, et al. EPZ011989, a potent, orally-available EZH2 inhibitor with robust in vivo activity. ACS Med Chem Lett. 2015;6(5):491-5.

92. Knutson SK, Kawano S, Minoshima Y, Warholic NM, Huang $\mathrm{KC}$, Xiao Y, et al. Selective inhibition of EZH2 by EPZ-6438 leads to potent antitumor activity in EZH2-mutant non-Hodgkin lymphoma. Mol Cancer Ther. 2014;13(4):842-54.

93. Kim W, Bird GH, Neff T, Guo G, Kerenyi MA, Walensky LD, et al. Targeted disruption of the EZH2-EED complex inhibits EZH2-dependent cancer. Nat Chem Biol. 2013;9(10):643-50. 